\title{
DOES IT PAY TO HAVE YOUR OWN R\&D \\ DEPARTMENT? IN-HOUSE AND EXTERNAL R\&D IN THE CONTEXT OF INNOVATIONS
}

\author{
Jacek Lewkowicz a,b (iD), Anna Lewczuk ${ }^{a}$ (iD
}

\begin{abstract}
What type of R\&D is essential for creating innovations? Is in-house R\&D more efficient than purchasing external innovations? The question of various strategies for private firms to succeed in developing innovations is key for ongoing national and international programmes for raising innovativeness of economies. The goal of the paper is to investigate the outcomes of different types of R\&D in the context of innovations and to analyse their significance in European countries empirically. In this paper, we aim to provide a quantitative analysis of the problem on the data collected from the Common Innovation Survey. We cover innovations in products, services, production methods, distribution systems and supporting activities. The results suggest that both in-house and external R\&D matter for firms' innovativeness, but the effect is stronger for the former for most of the types of innovations considered.
\end{abstract}

Keywords: Innovations, internal R\&D, external R\&D

JEL Classification: D22, O31, O32, O33

\section{Introduction}

What is a better way to develop innovations: through in-house R\&D or external R\&D? We ask this question with reference to market institutional frameworks.

It is essential to understand why firms develop innovations. Research and development may be quite money- and time-consuming, as well as risky. However, some firms still do their best in developing various innovations. Firms are aiming at taking the market leadership and benefit from that type of economic rent. But to do so, they have to invest in R\&D.

Innovators may undertake various strategies of developing innovations. Entities may create innovations by themselves (in-house R\&D), by buying semi-products and

\footnotetext{
a University of Warsaw, Faculty of Economic Science, Warsaw, Poland

b National Bank of Poland, Warsaw, Poland

Email: jlewkowicz@wne.uw.edu.pl, alewczuk@wne.uw.edu.pl
} 
technology (external R\&D) and based on some kind of cooperation. In our research, we refer to the existing literature on the issue and then we check the expectations empirically, focusing on European states. In particular, we analyse the significance and impacts of internal and external R\&D with regard to efficiency in developing innovations.

The paper covers an empirical perspective on the issue of internal and external $R \& D$ performed by innovative firms. We analyse the characteristics of the two types of R\&D in European firms with a particular interest in their relevance for success in introducing market innovations. Our research aims to add value to the broad current discussion of innovativeness.

\section{In-house and External $R \& D$}

Internal R\&D and external acquisition of innovations have been compared to assess complementarity or substitutability effects in innovative activities. Sometimes, the boundary between external and internal projects may be explained with reference to potential of sunk costs (Ulset, 1996). Empirical analyses suggest that internal R\&D and external knowledge acquisition are somehow complementary innovation activities, but the degree of their complementarity is sensitive to other elements of the firm's strategic environment (Cassiman and Veugelers, 2006b). Other findings suggest that such complementarity occurs with a positive impact of external R\&D evident only in the case of sufficient internal R\&D (Belderbos et al., 2004). Internal R\&D and external R\&D are complementary innovation activities at higher levels of in-house R\&D investments (Hagedoorn and Wang, 2012). It also turns out that internal $R \& D$ matters for enhancing absorptive capacity of entities. Thus, firms are more prone to be engaged in R\&D cooperation when they spend relatively more on internal R\&D (Veugelers, 1997). R\&D cooperation has, in turn, a positive influence on internal $R \& D$, but only when firms have an adequate absorptive capacity (e.g., full-time staffed R\&D department) (Veugelers, 1997). What is essential, even if internal R\&D is not an obligatory precondition for a firm to develop innovations, it should still be carried out, because of its key role in generating synergies that boost the effects of other innovative inputs that it interacts with (Catozzella and Vivarelli, 2014).

Complementarity between internal and external innovation activities is found to be dependent on the roles of universities and research centres as information sources for the innovation process (Cassiman and Veugelers, 2006a). It is also proven that innovation rates are significantly higher among firms that subcontract specialized technical work to external consultants (Makun and Macpherson, 1997). A moderate degree of R\&D outsourcing leads to a better output in innovations (Berchicci, 2013). The positive impact 
of external R\&D on a firm's performance with regard to innovations increases along with in-house R\&D efforts (Tsai and Wang, 2008). On the other hand, a vastly greater degree of R\&D outsourcing seems to reduce a firm's innovative output. However, a firm's R\&D capacity is crucial in this context.

Firms that are involved in a single innovation strategy, either internal R\&D activities or sourcing technology externally, tend to introduce fewer new or substantially improved products than firms that combine internal and external sourcing (Cassiman and Veugelers, 2006b). This is an additional argument for considering complementarity between internal and external R\&D. Moreover, internal R\&D and external $R \& D$ may be characterized as substitutive options only for lower levels of in-house R\&D efforts. It turns out that firms, when considering accessing knowledge from outside, take into account the openness to new ideas and codifiability of the knowledge (Fey and Birkinshaw, 2005). It seems that stopping $R \& D$ acquisition from other firms may have a positive impact on internal $R \& D$ activity. However, it does not mean better efficiency in developing innovations (Teirlinck et al., 2010).

Another issue is that a decision whether to enter into an external R\&D relationship is related to a prior decision to carry out R\&D (Piga and Vivarelli, 2004). Empirical comparison of outcomes of in-house and external R\&D suggests that significant innovations are mostly generated in-house, whereas contracted $R \& D$ seems to be more oriented towards innovations of an incremental nature (Beneito, 2006). Studies imply a nonlinear relationship between productivity and the share of external R\&D for higher-technology industries, which hints at decreasing productivity effects of an increasing share of external R\&D to the total (Bönte and Nielsen, 2010).

An interesting aspect is the choice between internal and external $R \& D$ with reference to costs of innovations. It is found that firms consider the scale of investments to be made, R\&D input as well as market structure characteristics while considering modes of R\&D (Love et al., 2010). In addition, it seems that intangible factors are the main cause of the probability that a firm will perform internal R\&D (Del Canto and González, 1999). An additional fact is that governmental policy designed to stimulate technological progress by offering external research facilities is especially attractive for small and capital-intensive organizations, which operate on relatively less concentrated markets (Van Dijk et al., 1997). It is also discussed that external technology acquisitions are more likely to occur when the number of rivals expected to develop a similar product is greater and the required technology is less related to a firm's baseline technology (Kurokawa, 1997). Moreover, it is claimed that firms decide to choose external R\&D in order to shorten the time necessary for $\mathrm{R} \& \mathrm{D}$ and maximize long-time profits during the lifetime of the innovation (Kurokawa, 1997). 
From another perspective, it is claimed that internal $R \& D$ does not influence the profitability of firms in a significant manner (Mata and Woerter, 2013). External R\&D, in turn, brings profits that may be described as more varied and have a larger number of extreme values. However, as those extreme values are distributed on the two tails of the distribution, the risk is greater than in the case of internal R\&D.

The available literature also suggests that there is a positive correlation between R\&D offshoring and innovation performance and that it affects product innovations more strongly than process innovations (Nieto and Rodriguez, 2011). What is crucial, technology acquisition is claimed to be the most efficient type of R\&D collaboration for service SMEs (Suh and Kim, 2014).

The issue of external knowledge and R\&D is not crucial only for innovativeness, but also plays a role in terms of overall commercial performance: entities combining internal innovation efforts with external $R \& D$ are usually better off compared to competitors who base their innovations on internal or external efforts separately (Macpherson, 1997).

\section{Other Determinants of Firms' Innovativeness}

The issue of the relationship between firm size, measured by number of employees or size of turnover, and innovations has been discussed abundantly in the literature. Large firms invest more in R\&D than smaller ones, which leads to a higher probability of developing innovations (Shefer and Frenkel, 2005; Cohen and Klepper, 1996). This general conclusion, that a significant and positive correlation between size of the entity and innovations exists, is confirmed by meta-analyses as well (Camison-Zomoza et al., 2004). In addition, up to a certain point, large organizations, as they have greater resources, seem to have higher chances of commercializing radically new products (Ettlie and Rubenstein, 1987). Big firms conduct $R \& D$ in a systematic way and it is generally more effective than occasional R\&D efforts in smaller firms (Santarelli and Strelacchini, 1990). However, a smaller firm may be more likely to become a leader on a totally new product market (Yin and Zuscovitch, 1998). Small firms are also the recipients of R\&D spillovers from academic centres or other large R\&D centres (Acs et al., 1994).

Human capital in innovative firms is another aspect of innovativeness. A positive relationship between human capital and innovation is generally confirmed (Dakhli and De Clercq, 2007). The level of human capital is approximated, inter alia, by the diplomas acquired (Goux and Maurin, 1994). This method is perceived as leading, easy to implement, but oversimplified. However, a high percentage of well-educated employees reflects a high level of human capital in a firm and should lead to occurrence of innovations and the firm's higher absorptive capacity (Vinding, 2001). Human capital has to achieve some critical levels necessary to reach faster total factor productivity growth (Benhabib and Spiegel, 
2005), which is in line, to some extent, with development of innovations. Thus, intellectual capital affects organizational performance in a significant manner (Youndt and Snell, 2004).

The state is in a position to introduce active policies devoted to enhancing innovativeness in the economy. Active pro-innovation policies and programmes can be considered as responses to some structural problems and a manner of popularizing innovative commercial activity (Jaumotte and Pain, 2005). These policies can be focused on practical outcomes of institutional settings of innovative activity and direct or indirect creation of ecosystems favourable for developing innovations. In particular, this could mean promoting commercialization of research ideas, co-operation between firms and the academic sector or transferring funds for selected types of entities (OECD, 2014). Such systems of public support have to be adaptive to the current needs of firms and business trends to correct potential mistakes in the allocation of funds.

Research reveals that public policies designed to support commercial innovations have to be flexible and adequate to needs of various types of firms. Public grants, subsidies or other forms of accountable financial support are more suitable for helping relatively big entities, inter alia, because of their ability to handle administrative obligations (European Commission, 2014). Grants and subsidies can be a crucial help in developing innovations, but they may entail serious bureaucratic duties and boost transaction costs accompanying innovative activities, which poses a serious barrier to smaller firms.

Innovations or expenses on R\&D are included in numerous models of economic growth (inter alia, Grossman and Helpman, 1991). On the other hand, a sound economic situation reflected by GDP per capita is in line with the ability to promote research clusters, development of financial markets that provide sources for R\&D or maturity of social capital, which boost innovativeness of firms (Breznitz, 2014; Berger and Udell, 2006; Kaasa, 2007). In addition, other macroeconomic factors, e.g., inflation, may also play a role, as it affects current allocation of resources (Brennan and Xia, 2002; Lee, 1992).

The literature reviewed in this paper is focused primarily on some of the internal factors influencing innovativeness of the economy. Naturally, there are also other relevant means that refer to international relations, political stability, international trade or international agreements that may be significant in terms of innovativeness (Felbermayr and Yalcin, 2013).

\section{Model and Results}

\subsection{Database and variables}

We employ firm-level data collected from the Community Innovation Survey (CIS), covering innovation activity of European enterprises. The CIS is conducted in waves with 
a two-year frequency and contains data from enterprises located in the European Union member states, Norway and Iceland. In our research, we apply the CIS 2014 wave with data collected in 2012 and 2014. After removing observations with missing dependent variables, the database consists of observations for 98,809 enterprises. Table 1 presents a list of fifteen countries included in CIS 2014 with the numbers of observations assigned. The number of enterprises varies across countries. About one third of the enterprises in the sample are located in Spain, while $15 \%$ is from Bulgaria.

Table 1: Countries included in the dataset

\begin{tabular}{|c|c|c|}
\hline Country & $\begin{array}{c}\text { Number } \\
\text { of observations }\end{array}$ & $\begin{array}{c}\text { Percentage } \\
\text { of sample }\end{array}$ \\
\hline Bulgaria & 14,255 & 14.43 \\
\hline Cyprus & 1,346 & 1.36 \\
\hline Czech Republic & 5,198 & 5.26 \\
\hline Germany & 6,282 & 6.36 \\
\hline Estonia & 1,760 & 1.78 \\
\hline Greece & 2,507 & 2.54 \\
\hline Spain & 30,333 & 30.70 \\
\hline Croatia & 3,265 & 3.30 \\
\hline Hungary & 6,817 & 6.90 \\
\hline Lithuania & 2,421 & 2.45 \\
\hline Latvia & 1,501 & 1.52 \\
\hline Norway & 5,045 & 5.11 \\
\hline Portugal & 7,083 & 7.17 \\
\hline Romania & 8,206 & 8.30 \\
\hline Slovakia & 2,790 & 2.82 \\
\hline Total & 98,809 & 100.00 \\
\hline
\end{tabular}

Source: Authors' own elaboration.

We refer to the different types of innovation activity represented by five variables:

- a binary variable inpdgd - takes the value 1 if the enterprise has introduced a new (from the perspective of the market) or significantly improved good,

- a binary variable inpdsv - takes the value 1 if the enterprise has introduced a new or significantly improved service, 
- a binary variable inpspd - takes the value 1 if the enterprise has introduced a new or significantly improved method of production,

- a binary variable inpslg - takes the value 1 if the enterprise has introduced a new or significantly improved logistic, delivery or distribution system,

- a binary variable inpssu - takes the value 1 if the enterprise has introduced a new or significantly improved supporting activity.

This approach, encompassing a range of product and process innovations, allows us to deepen our research into the probability of occurrence of various types of innovation activities.

The main goal of the empirical study is to check the effect of in-house and external (outsourced) R\&D on various types of innovation activities. We define the following variables related to in-house and outsourced R\&D: in-house_RD (a binary variable taking the value 1 if the enterprise has conducted innovation development by itself or together with other enterprises or institutions, and 0 otherwise) and outsourcing (a binary variable taking the value 1 if the enterprise has used innovation development conducted by other enterprises or institutions). It is possible for the given enterprise to be involved in both types of R\&D activities; therefore, the variables in-house_RD and outsourcing are not mutually exclusive.

What is more, we use a variety of control variables related to enterprise characteristics and economic situation in the country where it operates:

- $\quad$ enterprise size - the number of employees (less than 50 size 0, between 50 and 249 size 50, 250-499 size 250, more than 500 size 500). The larger the entity, the higher the probability that it will be involved in innovations;

- a set of binary variables indicating the presence of public support for innovations: public funding from local or regional authorities (funloc), public funding from central government (fungmt) and public funding from the EU (funeu). Public funding should boost chances for developing innovations;

- total enterprise turnover in 2012 (turn14). The higher the turnover, the higher the probability of innovation, as the firm has more money to spend on R\&D;

- an ordinal variable representing the fraction of employees with a university degree (empud). There are seven intervals: $0 \%, 1-4 \%, 5-9 \%, 10-24 \%, 25-49 \%, 50-74 \%$, and $75-100 \%$. A high percentage of well-educated employees indicates a high level of human capital in the firm and should therefore encourage occurrence of innovation activities in the firm (specific regularities depend on particular sectors - education in natural and exact sciences plays a vital role in high-tech industries). 
What is more, we account for country-specific characteristics by including country fixed effects in the regression. Table 2 presents descriptive statistics for all the variables used in the analysis.

Table 2: Descriptive statistics

\begin{tabular}{|c|c|c|c|}
\hline & & $\begin{array}{c}\text { Number } \\
\text { of observations }\end{array}$ & Percentage \\
\hline \multirow{2}{*}{ inpdgd } & 0 & 83,316 & 84.32 \\
\hline & 1 & 15,493 & 15.68 \\
\hline \multirow{2}{*}{ inpdsv } & 0 & 89,284 & 90.36 \\
\hline & 1 & 9,525 & 9.64 \\
\hline \multirow{2}{*}{ inpspd } & 0 & 84,981 & 86.01 \\
\hline & 1 & 13,828 & 13.99 \\
\hline \multirow{2}{*}{ inpslg } & 0 & 92,999 & 94.12 \\
\hline & 1 & 5,810 & 5.88 \\
\hline \multirow{2}{*}{ inpssu } & 0 & 86,376 & 87.42 \\
\hline & 1 & 12,433 & 12.58 \\
\hline \multirow{2}{*}{$\begin{array}{l}\text { in-house_RD } \\
\text { (product innovation) }\end{array}$} & 0 & 84,656 & 85.68 \\
\hline & 1 & 14,153 & 14.32 \\
\hline \multirow{2}{*}{$\begin{array}{l}\text { in-house_RD } \\
\text { (service innovation) }\end{array}$} & 0 & 90,307 & 91.40 \\
\hline & 1 & 8,502 & 8.60 \\
\hline \multirow{2}{*}{$\begin{array}{l}\text { in-house } R D \\
\text { (process innovation) }\end{array}$} & 0 & 81,273 & 82.25 \\
\hline & 1 & 17,536 & 17.75 \\
\hline \multirow{2}{*}{$\begin{array}{l}\text { outsourcing } \\
\text { (product innovation) }\end{array}$} & 0 & 97,326 & 98.50 \\
\hline & 1 & 1,483 & 1.50 \\
\hline \multirow{2}{*}{$\begin{array}{l}\text { outsourcing } \\
\text { (service innovation) }\end{array}$} & 0 & 97,505 & 98.68 \\
\hline & 1 & 1,304 & 1.32 \\
\hline \multirow{2}{*}{$\begin{array}{l}\text { outsourcing } \\
\text { (process innovation) }\end{array}$} & 0 & 95,520 & 96.67 \\
\hline & 1 & 3,289 & 3.33 \\
\hline \multirow{2}{*}{ funloc } & 0 & 94,975 & 96.12 \\
\hline & 1 & 3,834 & 3.88 \\
\hline \multirow{2}{*}{ fungmt } & 0 & 90,594 & 91.69 \\
\hline & 1 & 8215 & 8.31 \\
\hline \multirow{2}{*}{ funeu } & 0 & 94,346 & 95.48 \\
\hline & 1 & 4463 & 4.52 \\
\hline \multirow{2}{*}{ funrtd } & 0 & 97,252 & 98.42 \\
\hline & 1 & 1,557 & 1.58 \\
\hline \multirow{7}{*}{ empud } & $0 \%$ & 23,112 & 23.39 \\
\hline & $1 \%$ to $4 \%$ & 14,155 & 14.33 \\
\hline & $5 \%$ to $9 \%$ & 12,842 & 13.00 \\
\hline & $10 \%$ to $24 \%$ & 20,673 & 20.92 \\
\hline & $25 \%$ to $49 \%$ & 12,018 & 12.16 \\
\hline & $50 \%$ to $74 \%$ & 7,527 & 7.62 \\
\hline & $75 \%$ to $100 \%$ & 8,482 & 8.58 \\
\hline \multirow{2}{*}{ size 500} & 0 & 95,539 & 96.69 \\
\hline & 1 & 3,270 & 3.31 \\
\hline \multirow{2}{*}{ size250 } & 0 & 91,990 & 93.10 \\
\hline & 1 & 6,819 & 6.90 \\
\hline \multirow{2}{*}{ size50 } & 0 & 69,003 & 69.83 \\
\hline & 1 & 29,806 & 30.17 \\
\hline \multirow{2}{*}{ sizeo } & 0 & 39,895 & 40.38 \\
\hline & 1 & 58,914 & 59.62 \\
\hline turn14 & & 98,809 & $47,600,000$ \\
\hline
\end{tabular}

Source: Authors' own elaboration. 
Table 3 presents Pearson's correlation coefficients calculated for our key variables, i.e., different types of innovation activities and outsourcing or in-house development. It appears from the table that in-house $R \& D$ is correlated with the occurrence of innovation to a much greater extent than outsourced R\&D. This suggests that in-house R\&D may be perceived as a better strategy for innovation compared to outsourcing. This claim will be tested in the further parts of the paper.

Table 3: Correlation between key variables

\begin{tabular}{l|c|c|c|c|c|c}
\hline & $\begin{array}{c}\text { in-house_RD } \\
\text { (product } \\
\text { innovation) }\end{array}$ & $\begin{array}{c}\text { outsourcing } \\
\text { (product } \\
\text { innovation) }\end{array}$ & $\begin{array}{c}\text { in-house_RD } \\
\text { (service } \\
\text { innovation) }\end{array}$ & $\begin{array}{c}\text { outsourcing } \\
\text { (service } \\
\text { innovation) }\end{array}$ & $\begin{array}{c}\text { in-house_RD } \\
\text { (process } \\
\text { innovation) }\end{array}$ & $\begin{array}{c}\text { outsourcing } \\
\text { (process } \\
\text { innovation) }\end{array}$ \\
\hline inpdgd & 0.9411 & 0.2824 & - & - & - & - \\
\hline inpdsv & - & - & 0.925 & 0.3472 & - & - \\
\hline inpspd & - & - & - & - & 0.7466 & 0.1896 \\
\hline inpslg & - & - & - & - & 0.4645 & 0.1409 \\
\hline inpssu & - & - & - & - & 0.6256 & 0.3299 \\
\hline
\end{tabular}

Source: Authors' own elaboration.

\subsection{Econometric strategy}

The econometric methodology used in the study is threefold: it consists of a cross-section logit model, a propensity score matching and a generalized structural logit model. First of all, we estimate a logit model in order to verify the influence of in-house and outsourced R\&D on the probability of various types of innovation activity.

The key model regression is as follows:

innovation type $_{i}=\alpha_{i}+$ inhouse_R $_{-} D_{i}+$ outsourcing $_{i}+$ firm characteristics $_{i}+$ + country fixied effects ${ }_{i}+\varepsilon_{i}$

We repeat the regression five times in order to account for different types of innovation activities.

Secondly, we test the robustness of results using the propensity score matching method. Finally, we account for the fact that the development of different types of process innovation may have an impact on the introduction of a new or significantly improved good or service. In order to account for the aforementioned endogeneity, we estimate a generalized structural equation logit model taking the following functional form: 


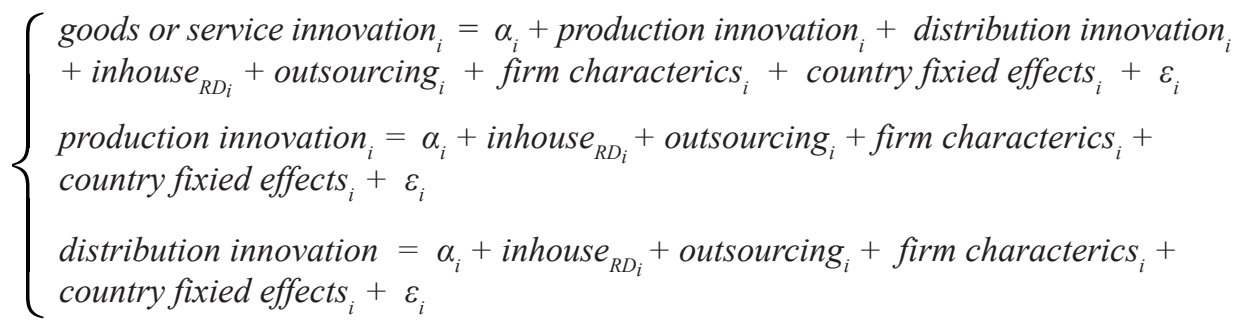

Our methodological approach adds value to the existing literature in two dimensions. Firstly, we employ a novel, advanced econometric method, i.e., a generalized structural equation logit model, to be able to account for the causality between process and product or service innovations. Secondly, we use a novel wave of data enabling verification of conclusions from the existing literature concerning innovations of enterprises.

\subsection{Empirical results}

Table 4 presents the outcomes of our logit estimation, explaining the impact of different R\&D types on the probability of firms' innovation activities. We account for the fact that in-house and outsourced R\&D may go hand in hand and we include both variables in the model. The results indicate that both types of R\&D increase the probability of every type of innovation activity and the effect is the strongest for the introduction of a new or significantly improved good (inpdgd). The effect is stronger for in-house R\&D, with the exception of the introduction of a new or significantly improved supporting activity (inpssu). The output of our empirical study generally confirms our expectations based on the literature (e.g., Berchicci, 2013; Catozzella and Vivarelli, 2014; Beneito, 2006; Veugelers, 1997).

What is more, the model outcomes indicate that the presence of public support increases the probability of the occurrence of a good (inpdgd), service (inpdsv) and method of production (inpspd) innovation, in line with the existing literature (e.g., Jaumotte and Pain, 2005). The larger the size of the enterprise and the higher the percentage of employees in the economy, the higher the probability of innovation, which is consistent with the available studies (e.g., Camison-Zomoza et al., 2004). The above results highlight the importance of human capital for innovation, fitting the results obtained, e.g., by Dakhli and De Clerq (2007) or Goux and Maurin (1994). 
Table 4: Results of logit estimation with country fixed effects

\begin{tabular}{|c|c|c|c|c|c|}
\hline & inpdgd & inpdsv & inpspd & inps/g & inpssu \\
\hline inhouse_RD & $\begin{array}{l}9.803^{*} \\
(81.08)\end{array}$ & $\begin{array}{l}9.237^{*} \\
(79.32)\end{array}$ & $\begin{array}{c}5.111^{*} \\
(126.43)\end{array}$ & $\begin{array}{l}3.883^{*} \\
(83.79)\end{array}$ & $\begin{array}{c}4.452 * \\
(115.72)\end{array}$ \\
\hline outsourcing & $\begin{array}{l}8.834^{*} \\
(34.78)\end{array}$ & $\begin{array}{l}8.545^{*} \\
(37.27)\end{array}$ & $\begin{array}{l}3.591^{*} \\
(63.21)\end{array}$ & $\begin{array}{c}1.959^{*} \\
(30.32)\end{array}$ & $\begin{array}{l}4.876^{*} \\
(89.08)\end{array}$ \\
\hline funloc & $\begin{array}{c}0.674 * \\
(4.45)\end{array}$ & $\begin{array}{l}0.383^{*} \\
(2.39)\end{array}$ & $\begin{array}{c}0.464^{*} \\
(8.09)\end{array}$ & $\begin{array}{l}0.042 \\
(0.73) \\
\end{array}$ & $\begin{array}{l}0.054 \\
(1.09) \\
\end{array}$ \\
\hline fungmt & $\begin{array}{c}1.003^{*} \\
(8.41)\end{array}$ & $\begin{array}{c}0.393^{*} \\
(3.22)\end{array}$ & $\begin{array}{l}0.720^{*} \\
(17.33)\end{array}$ & $\begin{array}{c}-0.115^{*} \\
(-2.74)\end{array}$ & $\begin{array}{c}-0.140 * \\
(-3.77)\end{array}$ \\
\hline funeu & $\begin{array}{c}0.926^{*} \\
(5.82)\end{array}$ & $\begin{array}{c}0.921^{*} \\
(5.61)\end{array}$ & $\begin{array}{l}0.797^{*} \\
(12.49)\end{array}$ & $\begin{array}{l}0.03 \\
(0.5) \\
\end{array}$ & $\begin{array}{c}0.06 \\
(-1.12)\end{array}$ \\
\hline funrtd & $\begin{array}{c}-0.716^{*} \\
(-2.57)\end{array}$ & $\begin{array}{l}-0.438 \\
(-1.65)\end{array}$ & $\begin{array}{c}-0.468^{*} \\
(-4.51)\end{array}$ & $\begin{array}{l}-0.122 \\
(-1.25)\end{array}$ & $\begin{array}{l}0.182^{*} \\
(2.05)\end{array}$ \\
\hline turn14 & $\begin{array}{c}-0.000^{*} \\
(-3.08)\end{array}$ & $\begin{array}{c}0 \\
(-1.61)\end{array}$ & $\begin{array}{c}0 \\
(-0.25)\end{array}$ & $\begin{array}{c}0.000 * \\
(-3.9)\end{array}$ & $\begin{array}{c}0 \\
(-0.85)\end{array}$ \\
\hline empud: $0 \%$ & $\begin{array}{l}- \\
-\end{array}$ & $\begin{array}{l}- \\
-\end{array}$ & $\begin{array}{l}- \\
-\end{array}$ & $\begin{array}{l}- \\
-\end{array}$ & $\begin{array}{l}- \\
-\end{array}$ \\
\hline empud: $1 \%$ to $4 \%$ & $\begin{array}{c}0.339 * \\
(2.00) \\
\end{array}$ & $\begin{array}{c}-0.336 \\
(-1.91) \\
\end{array}$ & $\begin{array}{c}0.305^{*} \\
(4.56) \\
\end{array}$ & $\begin{array}{l}0.088 \\
(1.15) \\
\end{array}$ & $\begin{array}{l}-0.023 \\
(-0.35)\end{array}$ \\
\hline empud: $5 \%$ to $9 \%$ & $\begin{array}{l}0.711^{*} \\
(4.43)\end{array}$ & $\begin{array}{l}0.003 \\
(0.02) \\
\end{array}$ & $\begin{array}{c}0.381 * \\
(5.96)\end{array}$ & $\begin{array}{l}0.027 \\
(0.37) \\
\end{array}$ & $\begin{array}{l}0.028 \\
(0.46) \\
\end{array}$ \\
\hline empud: $10 \%$ to $24 \%$ & $\begin{array}{c}0.867^{*} \\
(6.00)\end{array}$ & $\begin{array}{c}0.225 \\
(1.6) \\
\end{array}$ & $\begin{array}{c}0.445^{*} \\
(7.89)\end{array}$ & $\begin{array}{l}0.122 \\
(1.86) \\
\end{array}$ & $\begin{array}{l}0.171^{*} \\
(3.18)\end{array}$ \\
\hline empud: $25 \%$ to $49 \%$ & $\begin{array}{c}0.895^{*} \\
(5.71)\end{array}$ & $\begin{array}{c}0.416^{*} \\
(2.74)\end{array}$ & $\begin{array}{l}0.115 \\
(1.89) \\
\end{array}$ & $\begin{array}{c}0.208^{*} \\
(2.99)\end{array}$ & $\begin{array}{c}0.539 * \\
(9.3)\end{array}$ \\
\hline empud: $50 \%$ to $74 \%$ & $\begin{array}{c}0.766^{*} \\
(4.35)\end{array}$ & $\begin{array}{c}0.705^{*} \\
(4.31)\end{array}$ & $\begin{array}{c}-0.207^{*} \\
(-3.05)\end{array}$ & $\begin{array}{l}0.139 \\
(1.81) \\
\end{array}$ & $\begin{array}{l}0.857^{*} \\
(13.31)\end{array}$ \\
\hline empud: $75 \%$ to $100 \%$ & $\begin{array}{c}0.547^{*} \\
(3.11) \\
\end{array}$ & $\begin{array}{c}0.944^{*} \\
(6.15) \\
\end{array}$ & $\begin{array}{c}-0.308^{*} \\
(-4.54) \\
\end{array}$ & $\begin{array}{l}0.114 \\
(1.49) \\
\end{array}$ & $\begin{array}{l}0.836^{*} \\
(13.17) \\
\end{array}$ \\
\hline sizeo & $\begin{array}{l}- \\
-\end{array}$ & $\begin{array}{l}- \\
- \\
\end{array}$ & $\begin{array}{l}- \\
-\end{array}$ & $\begin{array}{l}- \\
- \\
\end{array}$ & $\begin{array}{l}- \\
-\end{array}$ \\
\hline size500 & $\begin{array}{l}0.315 \\
(1.42)\end{array}$ & $\begin{array}{l}0.761^{*} \\
(3.63)\end{array}$ & $\begin{array}{l}-0.037 \\
(-0.48)\end{array}$ & $\begin{array}{c}0.782^{*} \\
(10.26)\end{array}$ & $\begin{array}{l}0.920 * \\
(12.74)\end{array}$ \\
\hline size250 & $\begin{array}{c}0.528^{*} \\
(3.86)\end{array}$ & $\begin{array}{c}0.656^{*} \\
(4.96)\end{array}$ & $\begin{array}{c}0.086 \\
(1.7)\end{array}$ & $\begin{array}{l}0.520 * \\
(10.27)\end{array}$ & $\begin{array}{l}0.557^{*} \\
(11.89)\end{array}$ \\
\hline size50 & $\begin{array}{c}0.314^{*} \\
(3.7)\end{array}$ & $\begin{array}{l}0.155 \\
(1.74) \\
\end{array}$ & $\begin{array}{l}0.019 \\
(0.58)\end{array}$ & $\begin{array}{c}0.201^{*} \\
(5.38)\end{array}$ & $\begin{array}{c}0.277^{*} \\
(8.83)\end{array}$ \\
\hline cons & $\begin{array}{l}-5.638^{*} \\
(-35.93)\end{array}$ & $\begin{array}{l}-6.028^{*} \\
(-34.41) \\
\end{array}$ & $\begin{array}{l}-4.962^{*} \\
(-65.46) \\
\end{array}$ & $\begin{array}{l}-5.329^{*} \\
(-59.95)\end{array}$ & $\begin{array}{l}-5.257^{*} \\
(-70.13)\end{array}$ \\
\hline Number of observations & 98,809 & 98,809 & 98,809 & 98,809 & 98,809 \\
\hline LR chi2 & $77,591.76$ & $54,867.14$ & $48,093.2$ & $17,122.95$ & $39,921.59$ \\
\hline McKelvey and Zavoina's R2 & 0.83 & 0.761 & 0.606 & 0.451 & 0.584 \\
\hline \multicolumn{6}{|c|}{ link test } \\
\hline Prediction squared & 0.000359 & 0.003465 & 0.060242 & 0.007319 & 0.009744 \\
\hline t-statistics & $(0.07)$ & $(0.63)$ & $(0.56)$ & $(0.06)$ & $(0.78)$ \\
\hline
\end{tabular}

Note: Values of z-statistics in brackets. ${ }^{*}$ Significant at $5 \%$ level.

Source: Authors' own elaboration. 
In order to test the goodness of fit of the above model, we conduct a link test. The test is based on the idea that no additional independent variables shall be significant for a properly specified regression equation. The link test is able to detect a specification error called a link error, wherein a dependent variable needs to be transformed to accurately relate to an independent variable. The link test adds a squared independent variable to the model and tests for significance versus the non-squared model. A model without a link error will have a non-significant t-test versus the unsquared version. The results indicate that our regressions are properly specified. What is more, we report the values of McKelvey and Zavoina's $\mathrm{R}^{2}$, measuring the fit of logistic regression.

In the next step of our research, we test the robustness of our results using the propensity score matching (PSM) method. We check and compare the difference between average probability of occurrence of investment activity for firms that conducted in-house and outsourced R\&D. The similarity is measured using the univariate propensity score. The propensity score is calculated with the use of a logit model including all the covariates mentioned in the specifications above (i.e., firm-level and country-level characteristics). The matching estimates of the impact of in-house and outsourced R\&D on innovation activity are presented in Table 5 .

Table 5: Matching estimates of differences in innovation activity

\begin{tabular}{|c|c|c|c|c|c|c|c|c|c|c|}
\hline & \multicolumn{2}{|c|}{ inpdgd } & \multicolumn{2}{|c|}{ inpdsv } & \multicolumn{2}{|c|}{ inpspd } & \multicolumn{2}{|c|}{ inpslg } & \multicolumn{2}{|c|}{ inpssu } \\
\hline & \multicolumn{10}{|c|}{ Treatment criterion } \\
\hline & 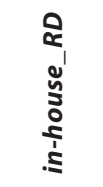 & 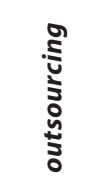 & 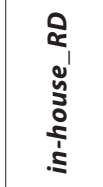 & $\begin{array}{l}0 \\
\text { : } \\
\vdots \\
0 \\
\vdots \\
\vdots \\
0\end{array}$ & 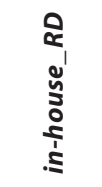 & 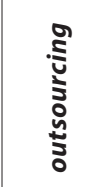 & 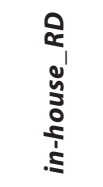 & 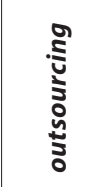 & 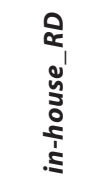 & 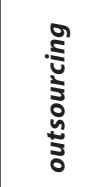 \\
\hline $\begin{array}{l}\text { Average } \\
\text { treatment } \\
\text { effect } \\
\text { on the treated }\end{array}$ & 0.975 & 0.838 & 0.971 & 0.882 & 0.632 & 0.319 & 0.265 & 0.168 & 0.485 & 0.568 \\
\hline $\begin{array}{l}\text { Standard } \\
\text { error }\end{array}$ & 0.001 & 0.005 & 0.004 & 0.019 & 0.007 & 0.018 & 0.006 & 0.020 & 0.007 & 0.021 \\
\hline Z-stat & 922.55 & 181.06 & 220.46 & 46.93 & 86.78 & 17.50 & 41.57 & 8.56 & 66.57 & 27.37 \\
\hline $\begin{array}{l}\text { Number of } \\
\text { observations }\end{array}$ & 98,809 & 98,809 & 98,809 & 98,809 & 98,809 & 98,809 & 98,809 & 98,809 & 98,809 & 98,809 \\
\hline
\end{tabular}

Source: Authors' own elaboration. 
Table 6: Results of generalized structural equation logit regression with country fixed effects

\begin{tabular}{|c|c|c|c|c|c|c|}
\hline & inpdgd & inpspd & inpslg & inpdsv & inpspd & inpslg \\
\hline inpspd & $\begin{array}{l}1.583^{* * *} \\
(17.00)\end{array}$ & $\begin{array}{l}- \\
- \\
\end{array}$ & $\begin{array}{l}- \\
- \\
\end{array}$ & $\begin{array}{l}1.076^{* * *} \\
(11.17) \\
\end{array}$ & $\begin{array}{l}- \\
- \\
\end{array}$ & - \\
\hline inpslg & $\begin{array}{l}0.697^{* * *} \\
(5.95) \\
\end{array}$ & $\begin{array}{l}- \\
- \\
\end{array}$ & - & $\begin{array}{l}1.010^{* * * *} \\
(8.84) \\
\end{array}$ & - & - \\
\hline inhouse_RD & $\begin{array}{l}9.716^{* * * *} \\
(78.96) \\
\end{array}$ & $\begin{array}{c}5.111^{* * * *} \\
(126.43) \\
\end{array}$ & $\begin{array}{l}3.883^{* * *} \\
(83.79) \\
\end{array}$ & $\begin{array}{l}9.088^{* * *} \\
(77.3)\end{array}$ & $\begin{array}{c}5.111 * * * \\
(126.43) \\
\end{array}$ & $\begin{array}{l}3.883^{* * *} \\
(83.79) \\
\end{array}$ \\
\hline outsourcing & $\begin{array}{l}8.829 * * * \\
(34.59) \\
\end{array}$ & $\begin{array}{l}3.591^{* * *} \\
(63.21) \\
\end{array}$ & $\begin{array}{c}1.959 * * * \\
(30.32) \\
\end{array}$ & $\begin{array}{l}8.456^{* * *} \\
(36.72) \\
\end{array}$ & $\begin{array}{l}3.591 * * * \\
(63.21) \\
\end{array}$ & $\begin{array}{l}1.959^{* * *} \\
(30.32)\end{array}$ \\
\hline funloc & $\begin{array}{l}0.436^{* *} \\
(2.98)\end{array}$ & $\begin{array}{l}0.464^{* * *} \\
(8.09)\end{array}$ & $\begin{array}{l}0.042 \\
(0.73)\end{array}$ & $\begin{array}{l}0.182 \\
(1.18)\end{array}$ & $\begin{array}{l}0.464^{* * * *} \\
(8.09)\end{array}$ & $\begin{array}{l}0.042 \\
(0.73)\end{array}$ \\
\hline fungmt & $\begin{array}{l}0.581^{* * *} \\
(5.13)\end{array}$ & $\begin{array}{l}0.720^{* * *} \\
(17.33)\end{array}$ & $\begin{array}{c}-0.115^{* *} \\
(-2.74) \\
\end{array}$ & $\begin{array}{l}0.048 \\
(0.41) \\
\end{array}$ & $\begin{array}{l}0.720^{* * * *} \\
(17.33) \\
\end{array}$ & $\begin{array}{c}-0.115^{* *} \\
(-2.74) \\
\end{array}$ \\
\hline funeu & $\begin{array}{l}0.491^{* *} \\
(3.18)\end{array}$ & $\begin{array}{l}0.797^{* * *} \\
(12.49) \\
\end{array}$ & $\begin{array}{l}0.03 \\
(0.5) \\
\end{array}$ & $\begin{array}{l}0.562^{* * *} \\
(3.5)\end{array}$ & $\begin{array}{l}0.797^{* * *} \\
(12.49) \\
\end{array}$ & $\begin{array}{l}0.03 \\
(0.5) \\
\end{array}$ \\
\hline funrtd & $\begin{array}{l}-0.356 \\
(-1.29)\end{array}$ & $\begin{array}{c}-0.468^{* * *} \\
(-4.51)\end{array}$ & $\begin{array}{l}-0.122 \\
(-1.25)\end{array}$ & $\begin{array}{l}-0.215 \\
(-0.83)\end{array}$ & $\begin{array}{c}-0.468^{* * *} \\
(-4.51)\end{array}$ & $\begin{array}{l}-0.122 \\
(-1.25) \\
\end{array}$ \\
\hline turn14 & $\begin{array}{l}-0.000 * * * \\
(-4.04)\end{array}$ & $\begin{array}{c}0.000 \\
(-0.25) \\
\end{array}$ & $\begin{array}{l}0.000^{* * *} \\
(3.9)\end{array}$ & $\begin{array}{c}-0.000 * \\
(-1.96) \\
\end{array}$ & $\begin{array}{c}0.000 \\
(-0.25) \\
\end{array}$ & $\begin{array}{l}0.000 * * * \\
(3.9)\end{array}$ \\
\hline empud: $0 \%$ & $\begin{array}{l}- \\
-\end{array}$ & $\begin{array}{l}- \\
- \\
\end{array}$ & $\begin{array}{l}- \\
- \\
\end{array}$ & - & $\begin{array}{l}- \\
- \\
\end{array}$ & - \\
\hline empud: $1 \%$ to $4 \%$ & $\begin{array}{l}0.262 \\
(1.52) \\
\end{array}$ & $\begin{array}{l}0.305^{* * *} \\
(4.56)\end{array}$ & $\begin{array}{l}0.088 \\
(1.15) \\
\end{array}$ & $\begin{array}{c}-0.413^{*} \\
(-2.30)\end{array}$ & $\begin{array}{l}0.305^{* * *} \\
(4.56)\end{array}$ & $\begin{array}{l}0.088 \\
(1.15) \\
\end{array}$ \\
\hline empud: $5 \%$ to $9 \%$ & $\begin{array}{l}0.599^{* * *} \\
(3.67)\end{array}$ & $\begin{array}{l}0.381^{* * *} \\
(5.96)\end{array}$ & $\begin{array}{l}0.027 \\
(0.37) \\
\end{array}$ & $\begin{array}{c}-0.1 \\
(-0.60)\end{array}$ & $\begin{array}{l}0.381^{* * *} \\
(5.96)\end{array}$ & $\begin{array}{l}0.027 \\
(0.37) \\
\end{array}$ \\
\hline empud: $10 \%$ to $24 \%$ & $\begin{array}{l}0.705^{* * *} \\
(4.78) \\
\end{array}$ & $\begin{array}{l}0.445^{* * *} \\
(7.89)\end{array}$ & $\begin{array}{l}0.122 \\
(1.86) \\
\end{array}$ & $\begin{array}{l}0.062 \\
(0.44) \\
\end{array}$ & $\begin{array}{l}0.445^{* * *} \\
(7.89)\end{array}$ & $\begin{array}{l}0.122 \\
(1.86) \\
\end{array}$ \\
\hline empud: $25 \%$ to $49 \%$ & $\begin{array}{l}0.787^{* * *} \\
(4.94) \\
\end{array}$ & $\begin{array}{l}0.115 \\
(1.89) \\
\end{array}$ & $\begin{array}{c}0.208^{* *} \\
(2.99)\end{array}$ & $\begin{array}{l}0.306^{*} \\
(2.00)\end{array}$ & $\begin{array}{l}0.115 \\
(1.89) \\
\end{array}$ & $\begin{array}{l}0.208^{* *} \\
(2.99)\end{array}$ \\
\hline empud: $50 \%$ to $74 \%$ & $\begin{array}{l}0.686^{* * *} \\
(3.85)\end{array}$ & $\begin{array}{l}-0.207^{* *} \\
(-3.05)\end{array}$ & $\begin{array}{l}0.139 \\
(1.81) \\
\end{array}$ & $\begin{array}{l}0.682^{* * *} \\
(4.15)\end{array}$ & $\begin{array}{c}-0.207^{* *} \\
(-3.05)\end{array}$ & $\begin{array}{l}0.139 \\
(1.81) \\
\end{array}$ \\
\hline empud: $75 \%$ to $100 \%$ & $\begin{array}{l}0.477^{* *} \\
(2.69)\end{array}$ & $\begin{array}{c}-0.308^{* * *} \\
(-4.54)\end{array}$ & $\begin{array}{l}0.114 \\
(1.49) \\
\end{array}$ & $\begin{array}{l}0.977^{* * *} \\
(6.3)\end{array}$ & $\begin{array}{c}-0.308^{* * *} \\
(-4.54)\end{array}$ & $\begin{array}{l}0.114 \\
(1.49) \\
\end{array}$ \\
\hline sizeo & $\begin{array}{l}0.086 \\
(0.38) \\
\end{array}$ & $\begin{array}{l}-0.037 \\
(-0.48) \\
\end{array}$ & $\begin{array}{l}0.782^{* * *} \\
(10.26)\end{array}$ & $\begin{array}{l}0.547^{* *} \\
(2.61)\end{array}$ & $\begin{array}{l}-0.037 \\
(-0.48) \\
\end{array}$ & $\begin{array}{l}0.782^{* * *} \\
(10.26)\end{array}$ \\
\hline size250 & $\begin{array}{l}0.272 \\
(1.95) \\
\end{array}$ & $\begin{array}{c}0.086 \\
(1.7)\end{array}$ & $\begin{array}{l}0.520^{* * *} \\
(10.27)\end{array}$ & $\begin{array}{l}0.365^{* *} \\
(2.71)\end{array}$ & $\begin{array}{c}0.086 \\
(1.7)\end{array}$ & $\begin{array}{l}0.520^{* * *} \\
(10.27)\end{array}$ \\
\hline size50 & $\begin{array}{l}0.208^{*} \\
(2.43)\end{array}$ & $\begin{array}{l}0.019 \\
(0.58) \\
\end{array}$ & $\begin{array}{l}0.201^{* * *} \\
(5.38)\end{array}$ & $\begin{array}{l}0.044 \\
(0.49) \\
\end{array}$ & $\begin{array}{l}0.019 \\
(0.58) \\
\end{array}$ & $\begin{array}{l}0.201^{* * * *} \\
(5.38)\end{array}$ \\
\hline cons & $\begin{array}{l}-5.638^{* * *} \\
(-35.47)\end{array}$ & $\begin{array}{l}-4.962^{* * *} \\
(-65.46)\end{array}$ & $\begin{array}{l}-5.329 * * * \\
(-59.95)\end{array}$ & $\begin{array}{l}-6.060^{* * *} \\
(-34.21)\end{array}$ & $\begin{array}{l}-4.962^{* * *} \\
(-65.46)\end{array}$ & $\begin{array}{l}-5.329 * * * \\
(-59.95)\end{array}$ \\
\hline $\begin{array}{l}\text { Number } \\
\text { of observations }\end{array}$ & \multicolumn{3}{|c|}{98,809} & \multicolumn{3}{|c|}{98,809} \\
\hline LR chi2 & \multicolumn{3}{|c|}{$-33,422.767$} & \multicolumn{3}{|c|}{$-35,523.467$} \\
\hline
\end{tabular}

Note: Values of z-statistics in brackets. ${ }^{*}$ Significant at $5 \%$ level.

Source: Authors' own elaboration. 
The PSM results enrich the previous ones from the logit estimation by comparing the impact of in-house or outsourced R\&D on the probability of innovation occurrence. A higher probability of innovation is observed for the treated units, where the treatment criterion is set as conducting in-house or outsourced $R \& D$, and the effect is stronger for in-house $R \& D$ for all the types of innovation activities except innovation of supporting activities.

Furthermore, we propose an alternative specification accounting for the fact that sometimes investment in one type of innovation may reduce the costs of implementation of another type of innovation and, as a result, may increase the probability of its appearance. Such a phenomenon is most likely to occur when process and goods or service innovations go hand in hand, i.e., the introduction of a new method of production, distribution system or other supporting activity may go together and support the introduction of a product or service innovation. Not accounting for this potential source of endogeneity may result in a bias of estimators. In order to control for the aforementioned dependence, we estimate a generalized structural equation logit model controlling for potential interaction between process and product or service innovations.

Table 6 presents the outcome of a generalized structural equation logit model accounting for the impact of the development of different types of process innovations on the introduction of a new or significantly improved good or service. In general, the results confirm the outcomes from the simple logit model. What is more, the outcomes suggest that indeed the presence of process innovations such as introduction of a new method of production or distribution system increase the probability of the occurrence of a good or service innovation. The change in the methodology to the generalized structural equation logit does not undermine the results obtained from the simple logit regression: in-house and outsourced $R \& D$ remain significant positive determinants of all types of innovations and the effect remains stronger for in-house $R \& D$.

\section{Conclusions}

The main objective of the present paper was to contribute to a better understanding of the character and impact of internal as well as external R\&D. Recent cross-disciplinary studies regarding the relevance of market and institutional frameworks for providing innovations crucial to the market and society, which combine economics with legal and political science, reveal the importance of this topic. However, the issue of in-house and external R\&D seems to remain ambiguous.

The results of our empirical model indicate that both in-house and external types of $R \& D$ increase the probability of innovation activity and the effect is the strongest 
for the introduction of a new or significantly improved good. The effect is generally stronger for in-house R\&D, except supporting activities. As a robustness check, we perform a generalized structural equation logit regression accounting for the causal effect between a process innovation and a good or service innovation. The results suggest that the presence of process innovations, such as introduction of a new method of production or distribution system, increases the probability of the occurrence of a good or service innovation. What is more, the change in the methodology does not undermine the results obtained from the simple logit regression: in-house and outsourced $R \& D$ remain significant positive determinants of all types of innovations and the effect remains stronger for in-house R\&D.

We believe that the proposed research into types of $R \& D$ is a value added in terms of the methodological approach and the novel data set. The use of a generalized structural equation logit model enabled us to expand the model of determinants of innovations by accounting for the relationship between process and product or service innovations. What is more, we use a new wave of data not yet exploited by empirical research into innovations, which enables us to verify and enrich assumptions and conclusions from the existing empirical studies concerning innovation of enterprises. Such a systematic empirical analysis may allow formulating reliable and data-based recommendations for policies in order to create settings conducive to the optimal functioning of the innovation ecosystem.

\section{References}

Acs, Z., Audretsch, D., Feldman, M. (1994). R\&D Spillovers and Recipient Firm Size. The Review of Economics and Statistics, 76(2), 336-340, https://doi.org/10.2307/2109888

Belderbos, R., Carree, M., Lokshin, B. (2004). Cooperative R\&D and firm performance. Research Policy, 33(1), 1477-1492, https://doi.org/10.1016/j.respol.2004.07.003

Beneito, P. (2006). The Innovative Performance of In-house and Contracted R\&D in Terms of Patents and Utility Models. Research Policy, 35(4), 502-517, https://doi.org/10.1016/j. respol.2006.01.007

Benhabib, J., Spiegel, M. M. (2005). Human Capital and Technology Diffusion. Handbook of Economic Growth, 1(A), 935-966, https://doi.org/10.1016/s1574-0684(05)01013-0

Berchicci, L. (2013). Towards an Open R\&D System: Internal R\&D Investment, External Knowledge Acquisition and Innovative Performance. Research Policy, 42(1), 117-127, https://doi.org/10.1016/j.respol.2012.04.017

Berger, A., Udell, G. (2006). A More Complete Conceptual Framework for SME Finance. Journal of Banking \& Finance, 30(11), 2945-2966, https://doi.org/10.1016/j.jbankfin.2006.05.008 
Bönte, W., Nielsen, S. (2010). Innovation, Credit Constraints, and Trade Credit: Evidence from a Cross-country Study. Universitätsbibliothek Wuppertal, University Library. Schumpeter Discussion Papers No. 005.

Brennan, M., Xia, Y. (2002). Dynamic Asset Allocation under Inflation. The Journal of Finance, 57(3), 1201-1238, https://doi.org/10.1111/1540-6261.00459

Breznitz, D. (2014). The Cardinal Sins of Innovation Policy. Harvard Business Review, 7. [Retrieved 2020-04-03] Available at: https://hbr.org/2014/07/the-cardinal-sinsof-innovation-policy

Camison-Zomoza, C., Lapiedra-Alcami, R., Segarra-Cipres, M.,. et al. (2004). A Meta-analysis of Innovation and Organizational Size. Organization Studies, 25(3), 331-361, https://doi.org/10.1177/0170840604040039

Cassiman, B., Veugelers, R. (2006a). R\&D Cooperation and Spillovers: Some Empirical Evidence from Belgium. The American Economic Review, 92(4), 1169-1184, https://doi.org/10.1257/00028280260344704

Cassiman, B., Veugelers, R. (2006b). In Search of Complementarity in Innovation Strategy: Internal R\&D and External Knowledge Acquisition. Management Science, 52(1), iv-154, https://doi.org/10.1287/mnsc. 1050.0470

Catozzella, A., Vivarelli, M. (2014). The Catalysing Role of In-House R\&D in Fostering the Complementarity of Innovative Inputs. Industry and Innovation, 21(3), 179-196, https://doi.org/10.1080/13662716.2014.910890

Cohen, W., Klepper, S. (1996). A Reprise of Size and R\&D. The Economic Journal, 106(437), 925-951, https://doi.org/10.2307/2235365

Dakhli, M., De Clercq, D. (2007). Human Capital, Social Capital, and Innovation: A Multicountry Study. Entrepreneurship \& Regional Development, 16(2), 107-128, https://doi.org/10.1080/08985620410001677835

Del Canto, J., González, I. (1999). A Resource-based Analysis of the Factors Determining a Firm's R\&D Activities. Research Policy, 28(8), 891-905, https://doi.org/10.1016/ s0048-7333(99)00029-3

Ettlie, J., Rubenstein, A. (1987). Firm Size and Product Innovation. Journal of Product Innovation Management, 4(2), 89-108, https://doi.org/10.1111/1540-5885.420089

European Commission (2014). A Study on R\&D Tax Incentives. Final Report. European Commission. Luxembourg Taxation Papers Working Paper No. 52, https://doi.org/10.2778/29775

Felbermayr, G. J., Yalcin, E. (2013). Export Credit Guarantees and Export Performance: An Empirical Analysis for Germany. The World Economy, 36(8), 700-719, https://doi.org/10.1111/twec.12031

Fey, C., Birkinshaw, J. (2005). External Sources of Knowledge, Governance Mode, and R\&D Performance. Journal of Management, 31(4), 597-621, https://doi. org/10.1177/0149206304272346 
Goux, D., Maurin, E. (1994). Education, Experience et Salaires: Tendances Recentes et Evolution de Long Terme. Economie et Prevision, 116(5), 155-178, https://doi.org/10.3406/ecop.1994.5704

Grossman, G., Helpman, E. (1991). Innovation and Growth in the Global Economy. Cambridge, Massachusetts: The MIT Press. ISBN 0-262-57097-1.

Hagedoorn, J., Wang, N. (2012). Is there Complementarity or Substitutability between Internal and External R\&D Strategies? Research Policy, 41(6), 1072-1083, https://doi.org/10.1016/j.respol.2012.02.012

Jaumotte, F., Pain, N. (2005). An Overview of Public Policies to Support Innovation.

OECD Economics Department. Paris Working Papers No. 456, https://doi.org/10.1787/707375561288

Kaasa, A. (2007). Effects of Different Dimensions of Social Capital on Innovation: Evidence from Europe at Regional Level. University of Tartu, Faculty of Economics and Business Administration. Working Paper No. 69, http://doi.org/10.2139/ssrn.976871

Kurokawa, S. (1997). Make-or-buy Decisions in R\&D: Small Technology Based Firms in the United States and Japan. IEEE Transactions on Engineering Management, 44(2), 124-134, https://doi.org/10.1109/17.584921

Lee, B. (1992). Causal Relations Among Stock Returns, Interest Rates, Real Activity, and Inflation. The Journal of Finance, 47(4), 1591-1603, https://doi.org/10.1111/j.15406261.1992.tb04673.x

Love, J., Roper, S., Hewitt-Dundas, N. (2007). Service Innovation, Embeddedness and Business Performance: Evidence from Northern Ireland. Regional Studies, 44(8), 983-1004, https://doi.org/10.1080/00343400903401568

Macpherson, A. (1997). The Role of Producer Service Outsourcing in the Innovation Performance of New York State Manufacturing Firms. Annals of the Association of American Geographers, 87(1), 52-71, https://doi.org/10.1111/0004-5608.00041

Makun, P., Macpherson, D. (1997). Externally-assisted Product Innovation in the Manufacturing Sector: The Role of Location, Inhouse R\&D and Outside Technical Support. Regional Studies, 31(7), 659-668, https://doi.org/10.1080/00343409750130740

Mata, J., Woerter, M. (2013). Risky Innovation: The Impact of Internal and External R\&D Strategies Upon the Distribution of Returns. Research Policy, 42(2), 495-501, https://doi.org/10.1016/j.respol.2012.08.004

Nieto, J., Rodriguez, A. (2011). Offshoring of R\&D: Looking Abroad to Improve Innovation Performance. Journal of International Business Studies, 42(3), 345-361, https://doi.org/10.1057/jibs.2010.59

OECD (2014). OECD Science, Technology and Industry Outlook. Paris: OECD Publishing. ISBN 978-92-64-17039-1.

Piga, C., Vivarelli, M. (2004). Internal and External R\&D: A Sample Selection Approach. Oxford Bulletin of Economics and Statistics, 66(4), 457-482, https://doi.org/10.1111/j.1468-0084.2004.00089.x 
Santarelli, E., Strelacchini, A. (1990). Innovation, Formal vs. Informal R\&D, and Firm Size: Some Evidence from Italian Manufacturing Firms. Small Business Economics, 2(3), 223-228, https://doi.org/10.1007/bf00389530

Shefer, D., Frenkel, A. (2005). R\&D, Firm Size and Innovation: An Empirical Analysis. Technovation, 25(1), 25-32, https://doi.org/10.1016/s0166-4972(03)00152-4

Suh, Y., Kim, M-S. (2014). Internationally Leading SMEs vs. Internationalized SMEs: Evidence of Success Factors from South Korea. International Business Review, 23(1), 115-129, https://doi.org/10.1016/j.ibusrev.2013.03.002

Teirlinck, P., Dumont, M., Spithoven, A. (2010). Corporate Decision-making in R\&D Outsourcing and the Impact on Internal R\&D Employment Intensity. Industrial and Corporate Change, 19(6), 1741-1768, https://doi.org/10.1093/icc/dtq038

Tsai, K-H., Wang, J-Ch. (2008). External Technology Acquisition and Firm Performance: A Longitudinal Study. Journal of Business Venturing, 23(1), 91-112, https://doi.org/10.1016/j.jbusvent.2005.07.002

Ulset, S. (1996). R\&D Outsourcing and Contractual Governance: An Empirical Study of Commercial R\&D Projects. Journal of Economic Behavior \& Organization, 30(1), 63-82, https://doi.org/10.1016/s0167-2681(96)00842-6

Van Dijk, B., Den Hertog, R., Menkveld, B., et al. (1997). Some New Evidence on the Determinants of Large- and Small-Firm Innovation. Small Business Economics, 9(4), 335-343, https://doi.org/10.1023/A:1007995919950

Veugelers, R. (1997). Internal R\&D Expenditures and External Technology Sourcing. Research Policy, 26(3), 303-315, https://doi.org/10.1016/s0048-7333(97)00019-x

Vinding, A. (2001). Absorptive Capacity and Innovative Performance: A human Capital Approach. Economics of Innovation and New Technology, 15(4-5), 507-517, https://doi.org/10.1080/10438590500513057

Yin, X., Zuscovitch, E. (1998). Is Firm Size Conducive to R\&D Choice? A Strategic Analysis of Product and Process Innovations. Journal of Economic Behavior \& Organization, 35(2), 243-262, https://doi.org/10.1016/s0167-2681(98)00057-2

Youndt, M., Snell, S. (2004). Human Resource Configurations, Intellectual Capital, and Organizational Performance. Journal of Managerial Issues, 16(3), 337-360. Available at: https://www.jstor.org/stable/40604485 